\title{
A formação inicial em Letras: cenário de pesquisas que consideram a perspectiva do professor formador ${ }^{1}$
}

\section{Pre-service Languages and Literature Education: an overview of the studies considering the teacher educator's perspective}

Francini Percinoto Poliseli Corrêa*

Universidade Estadual do Paraná

Apucarana - Paraná / Brasil

\begin{abstract}
RESUMO: Esse trabalho tem por objetivo apresentar um panorama das pesquisas sobre a formação inicial em Letras/Inglês no Brasil que tenham gerado dados envolvendo e dando voz ao professor formador de Letras entre 1987 e 2012. A fim de atingir o objetivo, foi realizada uma busca bibliográfica no banco de teses e dissertações da CAPES a partir de termos chaves no campo assunto. Como resultados, aponto as instituições e regiōes do Brasil de realização de pesquisas com este foco; o período de crescimento de estudos sobre o tema; as áreas de atuação específica dos formadores investigados e os diferentes instrumentos para geração de dados. A expectativa é não só informar sobre pesquisas quanto ao professor formador, mas também possibilitar que se detectem lacunas sobre o tema que ainda necessitam ser investigadas.
\end{abstract}

PALAVRAS-CHAVE: formador de professores; formação inicial de professores de língua inglesa; levantamento bibliográfico.

ABSTRACT: This paper aims at presenting an overview of the studies on the pre-service English Languages and Literature education in Brazil that have raised data involving and giving voice to the university professor from 1987 to 2012. In order to achieve the goal, a bibliographical research was conducted

\section{*francinicorrea@yahoo.com.br}

${ }^{1}$ Essa pesquisa bibliográfica foi desenvolvida como parte da minha tese de doutorado, em andamento, com término previsto para 2016, sob orientação de Vera Lúcia Lopes Cristovão no Programa de Pós-Graduação em Estudos da Linguagem da Universidade Estadual de Londrina (UEL). 
at CAPES database on theses and dissertations using keywords related to this subject. The results pointed out to the institutions and areas where research on this topic was conducted, the period of growth in the number of studies, the specific field of work of the educators investigated and the different instruments used for data generation. We expect not only to inform about conducted studies on the university professor, but also to allow the identification of investigation gaps on this theme.

KEYWORDS: university professor; initial English language teacher education; bibliographical research.

\section{Introdução}

Especificamente, quanto ao ensino e formação de professores de línguas, Gimenez (2005) aponta o crescente número de trabalhos na área explorando os níveis pré e em serviço. A pesquisadora formadora discute sobre aqueles apresentados em eventos como o INPLA (Intercâmbio de Pesquisas em Linguística Aplicada) e CBLA (Congresso Brasileiro de Linguística Aplicada) bem como coletâneas publicadas por linguistas aplicados ${ }^{2}$. Já Ortenzi (2007) faz um levantamento de pesquisas sobre a formaçãa do formador de professores em evento de repercussão internacional: o I CLAFPL (Primeiro Congresso Latino Americano de Formação de Professores de Língua). Dentre os 385 trabalhos apresentados nesse evento, Ortenzi (op.cit.) destaca que apenas 15 abordaram o tema "A formação do formador de professores" 3 com enfoques bastante diversos ${ }^{4}$. Nesse conjunto são encontrados estudos sobre a) o papel do formador; b) as abordagens empregadas nas ações formativas e a relação entre estas e o conhecimento construído pelo aluno-professor; c) contribuições da pesquisa entre formadores para seu desenvolvimento profissional; d) o processo de tornar-se formador e o papel de comunidades virtuais, a criação de ambiente virtual

\footnotetext{
${ }^{2}$ As pesquisas mencionadas por Gimenez (2005) são: Almeida Filho (1999); Leffa (2001); Gimenez (2002; 2003); Celani (2002); Kleiman (2002); Barbara \& Ramos (2003); Freitas e Guilherme de Castro (2003); Consolo \& Vieira-Abrahão (2004); Magalhães (2004); Vieira-Abrahão(2004).

${ }^{3}$ Grifos da autora.

${ }^{4}$ Para maiores detalhes sobre os temas das pesquisas levantadas sobre o formador de professor, consultar Ortenzi , 2007, cap. 2.3 - A pesquisa dos formadores de professores (ORTENZI, 2007, p. 22-24).
} 
para interação textual em LI e a formação do formador decorrente dessa atividade; e) mudanças nas práticas de formadores e professores em formação por meio de sessões de reflexão; f) relações e construção de conhecimento na interação entre formadores e alunos/professores; g) cultura de avaliar da formadora; $h$ ) percepçõos sobre processo de explicitação de crenças por parte de formadores e alunos/professores; e, i) processo de conscientização social de formadores.

Em relação às pesquisas que enfocam os níveis de formação inicial e continuada, além do estudo de Ortenzi (2007), destaco, dentre outras pesquisas que apontam o baixo número de estudos sobre a formação do professor formador, aquelas desenvolvidas por Gil (2005) e Salomão (2011).

No levantamento desenvolvido por Gil (2005), há um único trabalho cujo tema foi a "formação dos formadores de professores" no qual o papel da pesquisa entre formadores é avaliado a partir das concepções e práticas desses agentes das ações formativas.

Salomão (2011) discorre em seu artigo que, embora haja pesquisas voltadas para a formação tanto inicial quanto continuada de professores com relação ao ensino aprendizagem de língua inglesa ${ }^{5}$ e pesquisas que buscam uma avaliação e reestruturação dos cursos de Letras em nosso país ${ }^{6}$ , muito pouco tem sido dito sobre a formação (inicial ou continuada) dos formadores de professores, ou seja, dos docentes em cursos de graduação ou pós-graduação em Letras encarregados da formação destes profissionais. A autora ainda pontua que, muitas vezes, o aluno acaba de sair da pósgraduação e vai atuar como professor em um curso de Letras pela primeira vez, sem ter nunca trabalhado com formação de professores. Além disso, Salomão (2011) alerta que é comum este aluno ter enfocado em sua pesquisa de pós-graduação aspectos sobre o ensino de línguas que não necessariamente conduzem à transposição direta de suas novas funções e às necessidades de alunos-professores em formação.

Dois anos após Salomão (2011) evidenciar esse baixo número de pesquisas sobre os professores-formadores, Calvo (2013) ressalta a emergência de algumas pesquisas cujo enfoque é o professor formador e suas práticas educacionais, conforme sintetizo no quadro 1, a seguir:

${ }^{5}$ Como exemplo dessas pesquisas Salomão (2011) referencia Gil (2005); Gimenez e Cristovão (2004); e Vieira-Abrahão (2004; 2006).

${ }^{6}$ Como exemplo dessas pesquisas Salomão (2011) menciona Paiva $(2004,2005)$ e Gimenez (2005a, b). 


\section{QUADRO 1}

Foco de pesquisas emergentes sobre o formador de professor

\begin{tabular}{|l|l|l|}
\hline \multicolumn{1}{|c|}{ Ano } & Título & Foco do estudo \\
\hline Freitas (2004) & $\begin{array}{l}\text { Ensino em time } \\
\text { por professoras- } \\
\text { formadoras (inglês): } \\
\text { um ritmo constante de } \\
\text { fragmentaçôes, fluidez, } \\
\text { contradiçôes. }\end{array}$ & $\begin{array}{l}\text { Configuração e construção de significados de uma } \\
\text { experiência de ensino em time constituída por três } \\
\text { formadoras de professores de inglês }\end{array}$ \\
\hline Ortenzi (2007) & $\begin{array}{l}\text { A produção coletiva de } \\
\text { um material pedagógico } \\
\text { para prática de ensino } \\
\text { de inglês. }\end{array}$ & $\begin{array}{l}\text { Potencial de aprendizagem e desenvolvimento } \\
\text { gerado pela produção coletiva de material } \\
\text { pedagógico para a prática de Ensino de Inglês }\end{array}$ \\
\hline Perin (2009) & $\begin{array}{l}\text { Emergência e } \\
\text { Construção de uma } \\
\text { comunidade de prática } \\
\text { de formadores de } \\
\text { professores de língua } \\
\text { inglesa }\end{array}$ & $\begin{array}{l}\text { Compreender como se dá o desenvolvimento } \\
\text { profissional de formadores de professores de inglês } \\
\text { em contexto brasileiro sob a ótica de participação } \\
\text { em comunidades de prática (CPs), especificamente } \\
\text { na comunidade denominada ENFOPLI - } \\
\text { Encontro de Formadores de Professores de Língua } \\
\text { Inglesa }\end{array}$ \\
\hline Halu (2010) & $\begin{array}{l}\text { Formação de } \\
\text { Formadoras de } \\
\text { professores de inglês em } \\
\text { contexto de formação } \\
\text { continuada (NAP- } \\
\text { UFPR) }\end{array}$ & $\begin{array}{l}\text { Investigar como se dá a formação contínua a } \\
\text { partir das práticas de ensino, aprendizagem e } \\
\text { pesquisa com as quais o formador universitário de } \\
\text { professores de língua inglesa se envolve. }\end{array}$ \\
\hline
\end{tabular}

Fonte: Calvo (2013)

Apesar de concordar com Calvo (2013) que estes estudos relacionamse ao professor formador, saliento distinções entre eles: dois deles estão centrados no formador que atua na formação inicial - como é o caso das pesquisas desenvolvidas por Freitas (2004) e Ortenzi (2007), já o de Perin (2009) focaliza espaços em que formadores discutem suas práticas podendo estas estarem voltadas tanto para o contexto de formação inicial quanto continuada, e o último deles, o estudo de Halu (2010), enfoca formadores atuando na formação continuada.

Com relação à formação do formador, Calvo (op.cit.) ainda menciona uma coletânea organizada por Gimenez (2007), a qual reúne estudos sobre a formação de professores sob diferentes vieses e, especificamente, em seu 
primeiro capítulo, Gimenez e Cristovão (2007) discutem a importante questão da pesquisa enquanto elemento de desenvolvimento profissional do formador.

Gimenez (2005) esclarece que vários têm sido os ângulos de abordagens sobre a formação do professor de línguas, mas que, qualquer tentativa de tratamento adequado dos desafios que a circundam demandaria múltiplos olhares e detalhadas análises. Concordo com a autora e defendo, também, a partir destes dados iniciais apresentados sobre a questão do número ainda incipiente de estudos sobre a formação do professor formador, que um destes olhares e análises esteja voltado para o desenvolvimento de pesquisas que explorem a formação do formador de professores em contexto de formação inicial assim como suas representações e avaliações quanto ao seu próprio agir.

\section{Mapeamento e considerações quanto a pesquisas sobre professores formadores de Letras}

Ao realizar um levantamento bibliográfico a partir da base de dissertações/teses da $\mathrm{CAPES}^{7}$ no intuito de verificar a existência de pesquisas que enfocassem, especificamente, o corpo docente de cursos de licenciatura em Letras/Inglês, também constatei a escassez de estudos nessa perspectiva. Essa precariedade pode ser observada, principalmente, se considerarmos o número de pesquisas que têm sido desenvolvidas sobre formação de professores de línguas em nível pré e em serviço, conforme apresentado anteriormente nos estudos mencionados por Gimenez (2005).

Minha busca no portal da CAPES consistiu em três etapas e foi realizada a partir das seguintes palavras-chave no campo assunto:

i) professores formadores na formação inicial de Letras/Inglês;

ii) trabalho dos professores formadores na formação inicial de Letras/Inglês;

iii) o professor formador de Letras.

${ }^{7} \mathrm{~A}$ busca no banco de teses e dissertações da Capes ocorreu de janeiro a setembro de 2013. 
Saliento que, como não houve restrição de datas, as buscas foram realizadas de janeiro a setembro de 2013, conforme período estabelecido para registro pelo banco de dados da CAPES, ou seja, de 1987 a 2012.

Na primeira busca - professores formadores na formação inicial de Letras/ Inglês - obtive como resultado seis pesquisas realizadas em nível de mestrado e nenhuma em nível de doutorado. No quadro 2, a seguir, apresento os autores e ano destas pesquisas assim como seus respectivos locais de desenvolvimento, títulos, foco da pesquisa e instrumentos de geração de dados.

\section{QUADRO 2}

Busca 1: dissertações a partir das seguintes palavras-chave no campo assunto: professores formadores na formação inicial de Letras/Inglês

\begin{tabular}{|c|c|c|c|c|}
\hline Ano & Local & Título & Foco do estudo & $\begin{array}{l}\text { Instrumentos de geração } \\
\text { de dados }\end{array}$ \\
\hline $\begin{array}{l}\text { Silva } \\
(2005)\end{array}$ & $\begin{array}{l}\text { Universidade } \\
\text { Estadual de } \\
\text { Campinas. } \\
\text { Mestrado em } \\
\text { Linguística } \\
\text { Aplicada }\end{array}$ & $\begin{array}{l}\text { Crenças e } \\
\text { Aglomerados } \\
\text { de Crenças } \\
\text { de Alunos } \\
\text { Ingressantes em } \\
\text { Letras (Inglês). }\end{array}$ & $\begin{array}{l}\text { Crenças de alunos/ } \\
\text { professores, } \\
\text { possíveis origens e } \\
\text { sua influência na } \\
\text { prática pedagógica } \\
\text { do futuro professor. }\end{array}$ & $\begin{array}{l}\text {-Envolvendo professores } \\
\text { formadores: } \\
\text { i) Gravação de aulas em } \\
\text { áudio e vídeo (12 aulas } \\
\text { de LI). } \\
\text {-Envolvendo o aluno/ } \\
\text { professor: } \\
\text { ii) Gravação em áudio e } \\
\text { vídeo de (06) micro aulas } \\
\text { sendo uma (01) de cada } \\
\text { participante; } \\
\text { iii) Questionários; } \\
\text { iv) Entrevista } \\
\text { semiestruturadas. } \\
\text { - Envolvendo o } \\
\text { pesquisador: } \\
\text { iv) Observação direta de } \\
\text { aulas e micro aulas; } \\
\text { v) Anotações de campo } \\
\text { do pesquisador. }\end{array}$ \\
\hline
\end{tabular}




\begin{tabular}{|c|c|c|c|c|}
\hline $\begin{array}{l}\text { Agostini } \\
(2008)\end{array}$ & $\begin{array}{l}\text { Universidade } \\
\text { Federal de } \\
\text { Santa Maria. } \\
\text { Mestrado em } \\
\text { Educação }\end{array}$ & $\begin{array}{l}\text { A organização } \\
\text { e o desenvolvi- } \\
\text { mento de } \\
\text { estágios } \\
\text { curriculares } \\
\text { em cursos de } \\
\text { Licenciatura } \\
\text { da UFSM: } \\
\text { desenvolvi- } \\
\text { mento de } \\
\text { estagiários e } \\
\text { orientadores. }\end{array}$ & $\begin{array}{l}\text { Formas de } \\
\text { organização e } \\
\text { desenvolvimento } \\
\text { dos Estágios } \\
\text { Curriculares em } \\
13 \text { Cursos de } \\
\text { Licenciatura da } \\
\text { UFSM. }\end{array}$ & $\begin{array}{l}\text {-Envolvendo os } \\
\text { professores formadores } \\
\text { (docentes orientadores } \\
\text { de estágios dos Cursos de } \\
\text { Licenciatura da UFSM) } \\
\text { i) Entrevistas } \\
\text { estruturadas. } \\
\text { - Envolvendo o aluno/ } \\
\text { professor: } \\
\text { ii) Questionários; } \\
\text { iii) Grupos de discussão. } \\
\text {-Envolvendo coleta/ } \\
\text { análise documental: } \\
\text { iv) Projetos Pedagógicos } \\
\text { dos Cursos (PPC) e } \\
\text { normativas legais para a } \\
\text { Formação de Professores } \\
\text { da Educação Básica no } \\
\text { Brasil. }\end{array}$ \\
\hline $\begin{array}{l}\text { Silveira } \\
(2009)\end{array}$ & $\begin{array}{l}\text { Universidade } \\
\text { Federal } \\
\text { de Santa } \\
\text { Catarina. } \\
\text { Mestrado em } \\
\text { Linguística. }\end{array}$ & $\begin{array}{l}\text { O lugar dos } \\
\text { Gêneros nos } \\
\text { projetos e } \\
\text { relatórios } \\
\text { de estágio } \\
\text { do curso de } \\
\text { graduação em } \\
\text { Letras Inglês/ } \\
\text { Portu-guês da } \\
\text { Universidade } \\
\text { Regional de } \\
\text { Blumenau. }\end{array}$ & $\begin{array}{l}\text { Discurso do } \\
\text { professor em fase } \\
\text { final de formação } \\
\text { no contexto Curso } \\
\text { de Graduação } \\
\text { em Letras Inglês/ } \\
\text { Português no que se } \\
\text { refere à elaboração } \\
\text { do referencial } \\
\text { teórico e à } \\
\text { elaboração didática } \\
\text { da noção de gênero } \\
\text { do discurso para as } \\
\text { práticas de ensino- } \\
\text { aprendizagem de } \\
\text { leitura, escuta, } \\
\text { escrita e análise } \\
\text { linguística. }\end{array}$ & $\begin{array}{l}\text { - Envolvendo alunos } \\
\text { professores: } \\
\text { i) Projetos de estágio de } \\
\text { Língua Portuguesa (08); } \\
\text { ii) Relatórios de estágio } \\
\text { supervisionado (15) } \\
\text { iii) Relatórios analíticos } \\
\text { de estágio supervisionado } \\
\text { (17). } \\
\text { - Envolvendo coleta/ } \\
\text { análise documental: } \\
\text { iv) Grades curriculares } \\
\text { antigas (1998) e grade } \\
\text { curricular em vigor } \\
\text { (2004). }\end{array}$ \\
\hline
\end{tabular}




\begin{tabular}{|c|c|c|c|c|}
\hline $\begin{array}{l}\text { Registro } \\
(2010)\end{array}$ & $\begin{array}{l}\text { Universidade } \\
\text { Estadual de } \\
\text { Londrina. } \\
\text { Mestrado em } \\
\text { Estudos da } \\
\text { Linguagem }\end{array}$ & $\begin{array}{l}\text { A relação entre } \\
\text { prescrição, } \\
\text { representações } \\
\text { e agir docente: } \\
\text { um estudo } \\
\text { de caso em } \\
\text { um curso de } \\
\text { formação } \\
\text { inicial. }\end{array}$ & $\begin{array}{l}\text { Relação entre } \\
\text { as prescrições, } \\
\text { representações e } \\
\text { agir docente do } \\
\text { aluno-professor em } \\
\text { um curso de Letras } \\
\text { inglês-português, } \\
\text { diretamente ligadas } \\
\text { à área de língua } \\
\text { inglesa, a saber: } \\
\text { Língua Inglesa, } \\
\text { Literatura de } \\
\text { Língua Inglesa } \\
\text { (pesquisadora), } \\
\text { Metodologia de } \\
\text { Ensino de Língua } \\
\text { Inglesa e Literatura, } \\
\text { além de Estágio } \\
\text { Supervisionado. }\end{array}$ & $\begin{array}{l}\text { - Envolvendo professores } \\
\text { formadores (03): } \\
\text { i) Textos escritos em } \\
\text { resposta ao questionário; } \\
\text { ii) Trabalhos práticos } \\
\text { propostos aos alunos/ } \\
\text { professores. } \\
\text { - Envolvendo os alunos/ } \\
\text { professores (12): } \\
\text { ii) Textos orais produzidos } \\
\text { pelo grupo focal } \\
\text { constituído; } \\
\text { iii) Textos escritos em } \\
\text { resposta ao questionário } \\
\text { (perguntas abertas); } \\
\text { iv) Trabalhos práticos } \\
\text { desenvolvidos pelos } \\
\text { alunos-professores nas } \\
\text { disciplinas. } \\
\text { - Envolvendo coleta } \\
\text { documental: } \\
\text { v) PPC enfocando } \\
\text { prescrições ao aluno } \\
\text { professor. }\end{array}$ \\
\hline $\begin{array}{l}\text { El Kadri } \\
(2010)\end{array}$ & $\begin{array}{l}\text { Universidade } \\
\text { Estadual de } \\
\text { Londrina. } \\
\text { Mestrado em } \\
\text { Estudos da } \\
\text { Linguagem - }\end{array}$ & $\begin{array}{l}\text { O estatuto do } \\
\text { inglês como } \\
\text { língua franca } \\
\text { em um curso de } \\
\text { formação inicial } \\
\text { de professores }\end{array}$ & $\begin{array}{l}\text { Estatuto de inglês } \\
\text { como língua franca } \\
\text { em situaçōes- } \\
\text { problemas aplicadas } \\
\text { a alunos do quarto } \\
\text { ano do curso de } \\
\text { Letras-Inglês }\end{array}$ & $\begin{array}{l}\text { - Envolvendo professores } \\
\text { formadores }^{8}(01) \text { : } \\
\text { i) Entrevista } \\
\text { semiestruturada; } \\
\text { ii) Questionário aberto; } \\
\text { - Envolvendo os alunos/ } \\
\text { professores (29): } \\
\text { iii) Questionário aberto. } \\
\text { - Envolvendo coleta/ } \\
\text { análise documental: } \\
\text { iv) Programas de (05) } \\
\text { disciplinas optativas } \\
\text { (Gêneros Textuais para o } \\
\text { Ensino de LE; Introdução } \\
\text { a Tradução em LI; } \\
\text { Introdução à Linguística } \\
\text { Sistêmico Funcional; } \\
\text { Análise Crítica do } \\
\text { Discurso). }\end{array}$ \\
\hline
\end{tabular}

${ }^{8}$ Os formadores poderiam optar entre responder ao questionário ou participar da entrevista semiestruturada. 


\begin{tabular}{|c|c|c|c|c|}
\hline $\begin{array}{l}\text { Périllat } \\
(2011)\end{array}$ & $\begin{array}{l}\text { Pontifícia } \\
\text { Universidade } \\
\text { Católica de } \\
\text { São Paulo. } \\
\text { Mestrado em } \\
\text { Linguística } \\
\text { Aplicada } \\
\text { Estudos da } \\
\text { Linguagem }\end{array}$ & $\begin{array}{l}\text { A formação } \\
\text { inicial do } \\
\text { professor de } \\
\text { inglês: o olhar } \\
\text { do aluno. }\end{array}$ & $\begin{array}{l}\text { Organização } \\
\text { de um curso de } \\
\text { Letras/Inglês } \\
\text { e a formaçãoo } \\
\text { pedagógico- } \\
\text { prática nele } \\
\text { oferecida. }\end{array}$ & $\begin{array}{l}\text { - Envolvendo } \\
\text { professores formadores: } \\
\text { i) Observação de } 11 \\
\text { aulas; } \\
\text { ii) Gravação de } 04 \\
\text { aulas'; } \\
\text { iii) Material utilizado } \\
\text { pelo professor durante } \\
\text { as aulas observadas. } \\
\text { - Envolvendo alunos/ } \\
\text { professores (27): } \\
\text { iv) Questionário; } \\
\text { v) Material utilizado } \\
\text { pelos alunos em } \\
\text { suas apresentações } \\
\text { (microaulas) durante as } \\
\text { aulas observadas; } \\
\text { vi) Observação das } \\
\text { apresentaçôes dos } \\
\text { alunos. } \\
\text { - Envolvendo coleta/ } \\
\text { análise documental: } \\
\text { vii) Matriz curricular } \\
\text { da universidade; } \\
\text { viii) Programas de } \\
\text { ensino ( } 7 / 8 \text { ); } \\
\text { ix) Ementas de } \\
\text { professores formadores } \\
\text { participantes que } \\
\text { atuam na área de } \\
\text { Língua e Literatura } \\
\text { inglesa e formação } \\
\text { pedagógica (7/8). } \\
\text { - Envolvendo o } \\
\text { pesquisador: } \\
\text { x) Notas de campo. }\end{array}$ \\
\hline
\end{tabular}

Fonte: Elaborado pela autora a partir do banco de teses e dissertações da CAPES.

${ }^{9} \mathrm{O}$ capítulo de Périllat (2011) que se refere à metodologia mostrou-se bastante contraditório no que concerne aos participantes da pesquisa e os instrumentos de coleta de dados. 
Ao analisar o título das dissertações encontradas bem como seus resumos, nesta primeira busca, constatei que grande parte dos estudos não enfocava os professores formadores na formação inicial de Letras/Inglês sob a perspectiva do próprio formador. Desse modo, optei por não restringir a análise somente a estes dados para afirmar esta precariedade. Analisei também o capítulo referente à metodologia utilizada nestas pesquisas em relação aos objetivos, instrumentos utilizados para geração de dados assim como os sujeitos participantes. Observei que o foco das pesquisas, em geral, não se relacionava diretamente com as representaçôes do agir coletivo dos professores formadores que atuam em cursos de Licenciatura de Letras/ Inglês, mas sim a aspectos relacionados a resultados específicos/individuais de determinadas disciplinas constituintes da matriz curricular do curso no desenvolvimento do processo de ensino/ aprendizagem durante a formação inicial. Uma delas, a de Silveira (2009), na verdade, nem ao menos gera dados envolvendo o professor formador, apesar disto, eu a elenquei, pois está registrada no banco de dados da CAPES no campo assunto como pertencente a "professores formadores na formação inicial de Letras/Inglês".

Também observei, que dentre as demais cinco (05) pesquisas, relacionadas no portal da CAPES nesta primeira busca, em duas (02) delas - as de Silva (2005) e Périllat (2011) - o eixo central está na análise de aspectos relacionados à formação inicial do professor sob a perspectiva do aluno-professor. Embora o estudo de Périllat (op.cit.) se diferencie do de Silva (2005), por ter como fonte de dados tanto o currículo quanto os programas das disciplinas e a observação de aulas, o enfoque predominante da análise, assim como na pesquisa de Silva (2005), é na visão dos alunos sobre o curso, gerada por meio de questionários e não na visão de professores formadores destas disciplinas. Assim sendo, o cerne destas duas pesquisas reside no discurso do aluno-professor.

As pesquisas de El Kadri (2010) e Registro (2010) dão voz ao formador de professor embora restrinjam a geração de dados ao trabalho de professores formadores de disciplinas específicas da área de língua inglesa. Apesar dessa restrição, essas duas pesquisas são as únicas que estabelecem, como um de seus objetivos, enfocar as representações e o agir do formador de professores. Mas, além do formador de professores, os dois estudos focam também as relações entre as representações e agir docente em documentos prescritivos do curso de Letras e as representações dos alunos-professores. Outros aspectos comuns entre estas duas pesquisas estão no fato de terem sido desenvolvidas 
no ano de 2010 na mesma instituição de Ensino Superior e no mesmo programa de pós-graduação, mas com diferentes orientadores (UEL).

O estudo de Agostini (2008) assemelha-se aos de El Kadri (op.cit.) e Registro (2010) ao dar voz ao formador de professores. No entanto, diferencia-se de todos os demais estudos por abranger professores de estágio supervisionado provenientes de mais doze (12) Cursos Superiores de Licenciatura. Tal diferença justifica-se por esta ser a única pesquisa desenvolvida fora do âmbito da Linguística Aplicada ou de Estudos da Linguagem, pois está inserida em nível de Mestrado em Educação. Apesar disto, esta pesquisa, assim como as outras cinco aqui elencadas por meio da busca no banco de teses e dissertaçóes da CAPES, nesta primeira etapa, não abrange, especificamente, o assunto que pretendo investigar, qual seja, analisar como formadores de professores de um curso de Licenciatura em Letras/Inglês descrevem e compreendem o seu trabalho no contexto de formação inicial.

Percebendo este fato, passei para a segunda etapa da busca no banco de teses e dissertaçôes da CAPES, inserindo no campo assunto as seguintes palavras-chave: trabalho dos professores formadores na formação inicial de Letras/Inglês.

Nesta segunda etapa, obtive como resultado um número de 04 (quatro) dissertações e nenhuma tese relacionada ao assunto. No entanto, estas 04 (quatro) pesquisas já faziam parte daquelas 06 (seis) encontradas na primeira etapa, sejam elas: Silveira (2009), El Kadri (2010), Registro (2010) e Agostini (2008). Por tratar-se das mesmas dissertações apresentadas na primeira etapa, não discorrerei novamente sobre seus objetivos e a lente utilizada na geração e análise de dados.

Já na terceira etapa, tendo inserido no campo assunto - O professor formador de Letras - obtive como resultado um número bem maior de estudos: um total de cento e doze (112) pesquisas realizadas na área. Atribuo este aumento no número de pesquisas encontradas ao fato de ter incluído, nesta terceira busca, todos os cursos de Licenciatura em Letras podendo contemplar estudos tanto na área de Letras/Inglês, Letras/Português, Letras/ Espanhol ou ainda outras línguas. Dentre as pesquisas encontradas nesta etapa, procurei selecionar por meio da análise do resumo, aquelas cuja metodologia centrava seu estudo na geração e análise de dados dando voz ao formador de professores de Letras em contexto de formação inicial. Em vista desse critério, dentre estes 112 estudos, restrinjo minha apresentação a 
quinze (15), elencando em ordem cronológica as doze (12) dissertaçōes de mestrado e apenas três (03) teses de doutorado selecionadas, como pode ser observado no quadro 3 a seguir:

\section{QUADRO 3}

Busca 3: seleção de dissertações e teses que dão voz ao professor formador a partir das seguintes palavras-chave no campo assunto: o professor formador de Letras

\begin{tabular}{|c|c|c|c|c|}
\hline Auto & Local & Título & Foco do estudo & $\begin{array}{l}\text { Instrumentos de } \\
\text { geração de dados }\end{array}$ \\
\hline $\begin{array}{l}\text { Neder } \\
(1995)\end{array}$ & $\begin{array}{l}\text { Mestrado } \\
\text { em Linguística } \\
\text { Aplicada } \\
\text { Universidade } \\
\text { Estadual de } \\
\text { Campinas. }\end{array}$ & $\begin{array}{l}\text { Memória do } \\
\text { múltiplo e do } \\
\text { descontínuo } \\
\text { nos discursos de } \\
\text { construção de um } \\
\text { curso de Letras } \\
\text { de formação de } \\
\text { professores: IEL/ } \\
\text { UNICAMP. }\end{array}$ & $\begin{array}{l}\text { Concepções } \\
\text { e as crenças } \\
\text { subjacentes ao } \\
\text { discurso formador } \\
\text { nos programas } \\
\text { de disciplinas do } \\
\text { núcleo permanente } \\
\text { de três cursos } \\
\text { do IEL entre } \\
1978 \text { a 1992: } \\
\text { Licenciatura em } \\
\text { Letras/Português, } \\
\text { Bacharelado em } \\
\text { Linguística e } \\
\text { Bacharelado em } \\
\text { Letras }\end{array}$ & $\begin{array}{l}\text { - Envolvendo } \\
\text { professores } \\
\text { fundadores de } \\
\text { curso (02): } \\
\text { i) Entrevista com } \\
\text { professores } \\
\text { fundadores do } \\
\text { IEL. } \\
\text { - Envolvendo } \\
\text { coleta } \\
\text { documental: } \\
\text { ii) Programas de } \\
\text { disciplina de (03) } \\
\text { cursos; } \\
\text { iii) Histórico do } \\
\text { IEL/UNICAMP. }\end{array}$ \\
\hline Almeida (2004) & $\begin{array}{l}\text { Mestrado } \\
\text { em Letras } \\
\text { Universidade } \\
\text { Presbiteriana } \\
\text { Mackenzie. }\end{array}$ & $\begin{array}{l}\text { A prática do } \\
\text { professor } \\
\text { universitário: } \\
\text { o professor } \\
\text { formador de } \\
\text { professores de } \\
\text { língua inglesa } \\
\text { em diálogo com } \\
\text { seu referencial } \\
\text { teórico. }\end{array}$ & $\begin{array}{l}\text { A prática do } \\
\text { professor } \\
\text { universitário em } \\
\text { um Curso de } \\
\text { Graduação em } \\
\text { Letras de uma } \\
\text { instituição privada } \\
\text { de ensino superior }\end{array}$ & $\begin{array}{l}\text { - Envolvendo } \\
\text { professor } \\
\text { formador e aluno/ } \\
\text { professor: } \\
\text { i) Materiais } \\
\text { didáticos } \\
\text { fornecidos } \\
\text { aos alunos das } \\
\text { disciplinas } \\
\text { selecionadas no } \\
\text { estudo de caso, } \\
\text { realizado. }\end{array}$ \\
\hline
\end{tabular}




\begin{tabular}{|c|c|c|c|c|}
\hline Chiareli (2005) & $\begin{array}{l}\text { Mestrado em } \\
\text { Educação } \\
\text { Pontifícia } \\
\text { Universidade } \\
\text { Católica de } \\
\text { Campinas }\end{array}$ & $\begin{array}{l}\text { As abordagens } \\
\text { de ensino de } \\
\text { língua estrangeira } \\
\text { em cursos de } \\
\text { Letras: uma } \\
\text { visão do docente } \\
\text { formador. }\end{array}$ & $\begin{array}{l}\text { Conhecimento de } \\
\text { oito professores } \\
\text { formadores } \\
\text { docentes de } \\
\text { língua inglesa } \\
\text { de instituiçóes } \\
\text { mistas (pública, } \\
\text { confessional, } \\
\text { particular) sobre } \\
\text { abordagens de } \\
\text { ensino de língua } \\
\text { estrangeira em } \\
\text { cursos de Letras } \\
\text { e suas reflexões } \\
\text { sobre teoria e } \\
\text { prática pedagógicas }\end{array}$ & $\begin{array}{l}\text { Envolvendo } \\
\text { o professor } \\
\text { formador ( } 08 \text { de } \\
\text { LI): } \\
\text { i) Entrevistas } \\
\text { semiestruturadas; } \\
\text { ii) Questionário. }\end{array}$ \\
\hline $\begin{array}{l}\text { Gonçalves } \\
(2006)\end{array}$ & $\begin{array}{l}\text { Doutorado } \\
\text { em Letras pela } \\
\text { Universidade } \\
\text { Estadual Paulista } \\
\text { Júlio de Mesquita } \\
\text { Filho. }\end{array}$ & $\begin{array}{l}\text { Pressupostos } \\
\text { teóricos e } \\
\text { metodológicos } \\
\text { presentes na } \\
\text { prática do } \\
\text { docente formador } \\
\text { de professores de } \\
\text { inglês. }\end{array}$ & $\begin{array}{l}\text { Pressupostos } \\
\text { teóricos } \\
\text { metodológicos } \\
\text { subjacentes } \\
\text { à prática do } \\
\text { docente formador } \\
\text { de professores } \\
\text { de Inglês em } \\
\text { três cursos de } \\
\text { Licenciatura } \\
\text { em inglês e suas } \\
\text { influências na } \\
\text { formação do } \\
\text { professor. }\end{array}$ & $\begin{array}{l}\text { - Envolvendo } \\
\text { o professor } \\
\text { formador: } \\
\text { i) Observações } \\
\text { realizadas em salas } \\
\text { de aula de Inglês } \\
\text { em três cursos de } \\
\text { licenciatura em } \\
\text { Letras; } \\
\text { ii) Gravação e } \\
\text { transcrição de } \\
\text { aulas; } \\
\text { iii) Material } \\
\text { didático utilizado. } \\
\text { - Envolvendo } \\
\text { professor } \\
\text { formador e } \\
\text { alunos/professo- } \\
\text { res: } \\
\text { iv) Entrevista. }\end{array}$ \\
\hline
\end{tabular}




\begin{tabular}{|c|c|c|c|c|}
\hline $\begin{array}{l}\text { Souto } \\
(2007)\end{array}$ & $\begin{array}{l}\text { Mestrado em } \\
\text { Educação } \\
\text { pela Pontifícia } \\
\text { Universidade } \\
\text { Católica de São } \\
\text { Paulo. }\end{array}$ & $\begin{array}{l}\text { Ensinar a ensinar } \\
\text { e aprender } \\
\text { a ensinar: } \\
\text { representações } \\
\text { de professores e } \\
\text { alunos em relação } \\
\text { à formação inicial } \\
\text { dos cursos de } \\
\text { Licenciatura na } \\
\text { Universidade } \\
\text { Federal do } \\
\text { Amapá }\end{array}$ & $\begin{array}{l}\text { Representações de } \\
\text { quatro professoras } \\
\text { da disciplina } \\
\text { Didática dos cursos } \\
\text { de licenciatura } \\
\text { em Letras, } \\
\text { Matemática, } \\
\text { História e } \\
\text { Geografia bem } \\
\text { como de seus } \\
115 \text { licenciandos } \\
\text { sobre o aprender a } \\
\text { profissão docente. }\end{array}$ & $\begin{array}{l}\text {-Envolvendo } \\
\text { o professor } \\
\text { formador ( } 04 \\
\text { professoras } \\
\text { da disciplina } \\
\text { Didática dos } \\
\text { cursos de } \\
\text { Licenciatura em } \\
\text { Letras, Mat., Hist. } \\
\text { e Geog.); } \\
\text { i) Entrevistas. } \\
\text {-Envolvendo } \\
\text { alunos/professores } \\
\text { (115 licenciandos } \\
\text { em Letras, Mat., } \\
\text { Hist. e Geog.; } \\
\text { ii) Questionários. }\end{array}$ \\
\hline $\begin{array}{l}\text { Silva } \\
(2008)\end{array}$ & $\begin{array}{l}\text { Mestrado em } \\
\text { Letras pela } \\
\text { Universidade } \\
\text { Federal do Paraná }\end{array}$ & $\begin{array}{l}\text { Trabalho docente: } \\
\text { um estudo de } \\
\text { representação } \\
\text { em textos do } \\
\text { professor- } \\
\text { formador acerca } \\
\text { do papel da } \\
\text { disciplina de } \\
\text { língua inglesa no } \\
\text { curso de Letras. }\end{array}$ & $\begin{array}{l}\text { Representações } \\
\text { de professoras } \\
\text { formadoras da } \\
\text { disciplina de } \\
\text { Língua Inglesa } \\
\text { acerca do papel de } \\
\text { sua disciplina no } \\
\text { curso de Letras }\end{array}$ & $\begin{array}{l}\text { - Envolvendo } \\
\text { o professor } \\
\text { formador (02 } \\
\text { professoras da } \\
\text { disciplina de LI); } \\
\text { i) Filmagem de } \\
\text { aulas; } \\
\text { ii) Autoconfronta- } \\
\text { çôes simples e } \\
\text { cruzada; } \\
\text { iii) Extensão } \\
\text { ao coletivo do } \\
\text { trabalho (mais } \\
\text { 03 professoras } \\
\text { formadoras: a } \\
\text { pesquisadora } \\
\text { e mais 02 } \\
\text { professoras com } \\
\text { experiência nas } \\
\text { disciplinas de LI, } \\
\text { Literatura de LI, } \\
\text { Prática de Ensino } \\
\text { de LI, orientação } \\
\text { de estágio de LI, } \\
\text { coordenação do } \\
\text { Dept. de Letras } \\
\text { da instituição, } \\
\text { atuação na } \\
\text { Educação Básica } \\
\text { na área de LI). }\end{array}$ \\
\hline
\end{tabular}




\begin{tabular}{|c|c|c|c|c|}
\hline $\begin{array}{l}\text { Bomfim } \\
\text { (2008) }\end{array}$ & $\begin{array}{l}\text { Mestrado em } \\
\text { Linguística } \\
\text { Aplicada pela } \\
\text { Universidade de } \\
\text { Brasília }\end{array}$ & $\begin{array}{l}\text { Crenças em } \\
\text { relação à } \\
\text { formação inicial } \\
\text { de professor de } \\
\text { inglês e a prática } \\
\text { de ensino de } \\
\text { uma professora } \\
\text { formadora. }\end{array}$ & $\begin{array}{l}\text { Crenças e prática } \\
\text { de ensino de } \\
\text { uma professora } \\
\text { formadora } \\
\text { (Métodos e Prática } \\
\text { de Ensino da } \\
\text { Língua Inglesa) } \\
\text { em relação à } \\
\text { formação inicial de } \\
\text { professores de LE }\end{array}$ & $\begin{array}{l}\text { - Envolvendo } \\
\text { a professora } \\
\text { formadora: } \\
\text { i) Narrativas orais; } \\
\text { ii) Entrevista } \\
\text { semiestruturada; } \\
\text { iii) Observação, } \\
\text { transcrição e notas } \\
\text { de campo de aulas } \\
\text { com gravação em } \\
\text { áudio e vídeo; } \\
\text { iv) Sessões } \\
\text { reflexivas. }\end{array}$ \\
\hline $\begin{array}{l}\text { Lenz } \\
(2010)\end{array}$ & $\begin{array}{l}\text { Mestrado em } \\
\text { Educação pela } \\
\text { Universidade } \\
\text { Federal de Santa } \\
\text { Maria. }\end{array}$ & $\begin{array}{l}\text { A constituição } \\
\text { da docência no } \\
\text { Ensino Superior } \\
\text { em Letras: } \\
\text { de professor } \\
\text { da educação } \\
\text { básica a docente } \\
\text { universitário }\end{array}$ & $\begin{array}{l}\text { A constituição } \\
\text { da docência, a } \\
\text { experiência no } \\
\text { ensino básico e } \\
\text { sua repercussão } \\
\text { na atuação e } \\
\text { desenvolvimento } \\
\text { profissional de } \\
04 \text { formadoras } \\
\text { de professores de } \\
\text { Letras que atuam } \\
\text { na área de Língua } \\
\text { Portuguesa }\end{array}$ & $\begin{array}{l}\text { - Envolvendo } \\
\text { as professoras- } \\
\text { formadoras: } \\
\text { i) Entrevistas } \\
\text { narrativas } \\
\text { semiestruturadas. }\end{array}$ \\
\hline Saraiva (2010) & $\begin{array}{l}\text { Mestrado em } \\
\text { Educação pela } \\
\text { Universidade } \\
\text { Federal do Piauí }\end{array}$ & $\begin{array}{l}\text { Narrativas } \\
\text { sobre prática } \\
\text { pedagógica e } \\
\text { desenvolvimento } \\
\text { profissional: } \\
\text { Administrador } \\
\text { e professores } \\
\text { de ensino } \\
\text { superior como } \\
\text { protagonistas. }\end{array}$ & $\begin{array}{l}\text { A prática } \\
\text { pedagógica e } \\
\text { desenvolvimento } \\
\text { profissional no } \\
\text { Ensino Superior } \\
\text { na visão de } 05 \\
\text { Administradores- } \\
\text { professores; } \\
\text { pertencentes ao } \\
\text { Centro de Ciências } \\
\text { Humanas e Letras } \\
\text { e, neste, o curso } \\
\text { de Graduação em } \\
\text { Administração e } \\
\text { que integram o } \\
\text { corpo docente do } \\
\text { referido curso }\end{array}$ & $\begin{array}{l}\text {-Envolvendo } \\
\text { administradores } \\
\text { professores: } \\
\text { i) Entrevistas } \\
\text { narrativas } \\
\text { autobiográficas; } \\
\text { iii) Memorial de } \\
\text { formação. }\end{array}$ \\
\hline
\end{tabular}




\begin{tabular}{|c|c|c|c|c|}
\hline Barreto (2010) & $\begin{array}{l}\text { Doutorado em } \\
\text { Letras Neolatinas } \\
\text { pela Universidade } \\
\text { Federal do Rio de } \\
\text { Janeiro }\end{array}$ & $\begin{array}{l}\text { O professor } \\
\text { formador } \\
\text { de docentes } \\
\text { de Espanhol } \\
\text { como língua } \\
\text { estrangeira: } \\
\text { discursos sobre o } \\
\text { trabalho. }\end{array}$ & $\begin{array}{l}\text { Discursos que } \\
\text { circulam entre } 06 \\
\text { professores } \\
\text { formadores de } \\
\text { docentes de } \\
\text { espanhol como } \\
\text { língua estrangeira } \\
\text { em diferentes } \\
\text { Instituições e } 04 \\
\text { professores de } \\
\text { Língua Espanhola } \\
\text { do Ensino Básico } \\
\text { sobre sua atividade } \\
\text { de trabalho. }\end{array}$ & $\begin{array}{l}\text {-Envolvendo } \\
\text { professores } \\
\text { formadores e } \\
\text { professores do } \\
\text { Ensino básico } \\
\text { de Língua } \\
\text { Espanhola: } \\
\text { i) Entrevistas; } \\
\text { ii) Fórum de } \\
\text { discussão. }\end{array}$ \\
\hline $\begin{array}{l}\text { Costa } \\
(2010)\end{array}$ & $\begin{array}{l}\text { Doutorado em } \\
\text { Educação } \\
\text { Universidade } \\
\text { Federal de São } \\
\text { Carlos }\end{array}$ & $\begin{array}{l}\text { A docência } \\
\text { do professor } \\
\text { formador de } \\
\text { professores. }\end{array}$ & $\begin{array}{l}\text { Descrição e análise } \\
\text { que três professores } \\
\text { formadores } \\
\text { dos cursos de } \\
\text { Matemática e } \\
\text { Letras de uma } \\
\text { instituição pública } \\
\text { de ensino superior } \\
\text { do Estado da Bahia } \\
\text { fazem com relação } \\
\text { a sua docência na } \\
\text { licenciatura. }\end{array}$ & $\begin{array}{l}\text {-Envolvendo } \\
\text { professores } \\
\text { formadores } \\
\text { (cursos de } \\
\text { Licenciatura em } \\
\text { Matemática e } \\
\text { Letras): } \\
\text { i) Entrevistas } \\
\text { abordando } \\
\text { a formação } \\
\text { e a atuação } \\
\text { profissional } \\
\text { do professor } \\
\text { formador e o } \\
\text { seu ensino na } \\
\text { licenciatura. }\end{array}$ \\
\hline $\begin{array}{l}\text { Viana } \\
(2011)\end{array}$ & $\begin{array}{l}\text { Mestrado em } \\
\text { Linguística } \\
\text { Aplicada pela } \\
\text { Universidade de } \\
\text { Brasília Mestrado }\end{array}$ & $\begin{array}{l}\text { Baseado em fatos } \\
\text { reais: papéis do } \\
\text { formador na } \\
\text { (trans)forma- } \\
\text { ção inicial do } \\
\text { professor de } \\
\text { língua inglesa }\end{array}$ & $\begin{array}{l}\text { Papel de duas } \\
\text { professoras } \\
\text { formadoras } \\
\text { responsáveis pela } \\
\text { disciplina de } \\
\text { Metodologia de } \\
\text { Ensino de Línguas } \\
\text { Estrangeiras } \\
\text { Modernas } \\
\text { na (trans) } \\
\text { formação inicial } \\
\text { de professores } \\
\text { de língua } \\
\text { inglesa e as (in) } \\
\text { compatibilidades } \\
\text { entre essa atuação } \\
\text { e as exigências do } \\
\text { perfil de professor } \\
\text { egresso. }\end{array}$ & $\begin{array}{l}\text { - Envolvendo } \\
\text { as professoras } \\
\text { formadoras e } \\
\text { alunas professoras } \\
\text { (02): } \\
\text { i) Questionários; } \\
\text { ii) Entrevistas } \\
\text { semiestruturadas. } \\
\text { - Envolvendo a } \\
\text { pesquisadora: } \\
\text { iii) Observações } \\
\text { de aulas; } \\
\text { iv) Notas de } \\
\text { campo. }\end{array}$ \\
\hline
\end{tabular}




\begin{tabular}{|c|c|c|c|c|}
\hline $\begin{array}{l}\text { Teles } \\
(2011)\end{array}$ & $\begin{array}{l}\text { Mestrado em } \\
\text { Linguagem, } \\
\text { Cultura e } \\
\text { Discurso } \\
\text { UninCor } \\
\text { Universidade Vale } \\
\text { do Rio Verde, Três } \\
\text { Coraçōes } \\
\text { MG }\end{array}$ & $\begin{array}{l}\text { Memorial } \\
\text { reflexivo: história } \\
\text { e análise de } \\
\text { uma trajetória } \\
\text { profissional } \\
\text { docente }\end{array}$ & $\begin{array}{l}\text { A construção } \\
\text { do processo de } \\
\text { letramento e } \\
\text { suas repercussões } \\
\text { no exercício } \\
\text { profissional } \\
\text { docente, de uma } \\
\text { gestora educacional } \\
\text { e formadora de } \\
\text { professores, a } \\
\text { partir de seus } \\
\text { próprios dilemas e } \\
\text { questionamentos } \\
\text { sobre a sua } \\
\text { formação e } \\
\text { as práticas } \\
\text { decorrentes de } \\
\text { leitura e escrita. }\end{array}$ & $\begin{array}{l}\text { - Envolvendo } \\
\text { o trabalho da } \\
\text { pesquisadora/for- } \\
\text { madora: } \\
\text { i) Memorial } \\
\text { reflexivo e crítico. }\end{array}$ \\
\hline $\begin{array}{l}\text { Silva } \\
(2012)\end{array}$ & $\begin{array}{l}\text { Mestrado } \\
\text { em Estudos } \\
\text { Linguísticos pela } \\
\text { Universidade } \\
\text { Federal de } \\
\text { Uberlândia }\end{array}$ & $\begin{array}{l}\text { Cognições de } \\
\text { professores } \\
\text { sobre pesquisas } \\
\text { relacionadas } \\
\text { ao processo } \\
\text { de ensino e } \\
\text { aprendizagem de } \\
\text { LE - um estudo } \\
\text { "Q" }\end{array}$ & $\begin{array}{l}\text { Cognições de } \\
\text { professores- } \\
\text { em-serviço e } \\
\text { professores } \\
\text { formadores } \\
\text { quanto ao papel e } \\
\text { as contribuições } \\
\text { das pesquisas } \\
\text { em relação ao } \\
\text { processo de ensino } \\
\text { e aprendizagem } \\
\text { de LE. }\end{array}$ & $\begin{array}{l}\text { - Envolvendo } \\
\text { os professores } \\
\text { em serviço e } \\
\text { os professores } \\
\text { formadores de } \\
\text { LE: } \\
\text { i) Grupo focal; } \\
\text { ii) Entrevistas; } \\
\text { semiestruturadas } \\
\text { iii) Questionário } \\
\text { (Metodologia Q). }\end{array}$ \\
\hline
\end{tabular}




\begin{tabular}{|c|c|c|c|c|}
\hline $\begin{array}{l}\text { Danna }^{10} \\
(2012)\end{array}$ & $\begin{array}{l}\text { Mestrado em } \\
\text { Educação pela } \\
\text { Fundação } \\
\text { Universidade } \\
\text { Regional de } \\
\text { Blumenau }\end{array}$ & $\begin{array}{l}\text { Sentidos sobre } \\
\text { práticas de } \\
\text { leitura e escrita } \\
\text { em Letras: } \\
\text { com a palavra } \\
\text { professores } \\
\text { formadores. }\end{array}$ & $\begin{array}{l}\text { Sentidos que } \\
04 \text { professores } \\
\text { formadores } \\
\text { atuantes em } \\
\text { 03 diferentes } \\
\text { universidades } \\
\text { atribuem às } \\
\text { práticas de leitura } \\
\text { e escrita em } \\
\text { língua materna } \\
\text { nas } 12 \text { diferentes } \\
\text { disciplinas (teóricas } \\
\text { e práticas) que } \\
\text { lecionam nos seus } \\
\text { respectivos cursos } \\
\text { de Letras : } \\
\text { 1.Linguística Geral; } \\
\text { 2. Linguística } \\
\text { Aplicada; } \\
\text { 3.Metodologia } \\
\text { do Ensino de } \\
\text { Língua Portuguesa; } \\
\text { 4.Orientação de } \\
\text { Estágio de Língua } \\
\text { Portuguesa; } \\
\text { 5. Estágio de } \\
\text { Língua Portuguesa; } \\
\text { 6. Sintaxe e } \\
\text { Morfologia } \\
\text { Histórica do } \\
\text { Português; } \\
\text { 7. Estágio de } \\
\text { Língua Portuguesa; } \\
\text { 8. Fonética e } \\
\text { Fonologia; } \\
\text { 9. Estágio; } \\
\text { 10. Semântica; } \\
\text { 11. Produção e } \\
\text { Interpretação de } \\
\text { Texto; } \\
\text { 12. Redação } \\
\text { Técnica. } \\
\text { a }\end{array}$ & $\begin{array}{l}\text { - Envolvendo } \\
\text { professores } \\
\text { formadores } \\
\text { (disciplinas da } \\
\text { área de Língua } \\
\text { Materna com } \\
\text { relação às práticas } \\
\text { de leitura e } \\
\text { escrita); } \\
\text { i) Entrevista } \\
\text { narrativa. } \\
\text { - Envolvendo } \\
\text { coleta } \\
\text { documental: } \\
\text { ii) Planos de } \\
\text { ensino; } \\
\text { iii) Planos de aula; } \\
\text { iv) PPC de } \\
\text { Letras das } 03 \\
\text { Universidades. }\end{array}$ \\
\hline
\end{tabular}

Fonte: Elaborado pela autora a partir do banco de teses e dissertaçóes da CAPES.

${ }^{10}$ Dentre os quinze estudos desenvolvidos, este é o único em que a pesquisadora não atuava no contexto investigado. 
Estabelecendo um comparativo entre as pesquisas acima elencadas a partir das três buscas no portal da CAPES, sejam elas, i) professores formadores na formação inicial de Letras/Inglês; ii) trabalho dos professores formadores na formação inicial de Letras/Inglês; iii) o professor formador de Letras; passo a apresentar a seguir uma síntese destas quanto ao nível e área de conhecimento, abrangência em termos de regiões do Brasil em que estão localizadas as Instituições de Ensino Superior onde as pesquisas foram desenvolvidas, período de maior concentração de pesquisas sobre o tema, instrumentos para geração e análise dos dados e área de atuação dos formadores investigados.

Saliento que neste levantamento, sete (07), das vinte e uma (21) pesquisas selecionadas por meio das três buscas no portal da CAPES, não serão consideradas uma vez que não geraram dados dando voz ao professor formador de Letras em contexto de formação inicial, sejam elas, as de Silva (2005), Périllat (2011) e Silveira (2009) apresentadas no quadro 2 e, as de Neder (1995), Saraiva (2010), Barreto (2010) e Silva (2012) apresentadas no quadro 3.

As razões para desconsiderar as três primeiras - as de Silva (2005), Périllat (op.cit.) e Silveira (op.cit.) - já foram discutidas quando da apresentação da Busca 1. Quanto às quatro últimas pesquisas desconsideradas e que foram apresentadas no quadro 3 ( $3^{\text {a }}$ Busca), os motivos também estão embasados na questão de que elas não enfocam o agir do professor formador de Letras na formação inicial. A pesquisa de Neder (op.cit.), apesar de dar voz aos formadores, estes participam na posição de fundadores de cursos do Instituto de Estudos da Linguagem (IEL) de Licenciatura e Bacharelado na área de Letras contribuindo com dados acerca do percurso histórico do discurso formador nos programas de disciplinas do núcleo permanente daquela instituição. Por conseguinte, os instrumentos de geração de dados não são aplicados ao formador com relação a sua atuação na formação inicial. Já a pesquisa de Saraiva (2010) foca professores formadores da área de Letras que não atuam no curso de Licenciatura em Letras, mas sim em curso de Bacharelado em Administração. Há também dois outros estudos neste levantamento que não se restringiram aos professores formadores, mas que envolveram professores em serviço ou em formação continuada - o de Barreto (2010) e o de Silva (2012) - respectivamente.

Apresentadas essas consideraçôes, a síntese que realizo na sequência se restringi a 14 dentre as 21 pesquisas encontradas nas buscas 1 , 2 e 3 realizadas 
no banco de teses e dissertações, adotando como critério para essa seleção, a geração de dados enfocando a perspectiva do professor formador de Letras acerca de seu trabalho educacional.

\section{Nível e área de conhecimento das pesquisas}

Como discutido no tópico anterior e ilustrado nos quadros 2 e 3 e, no gráfico 1 , a seguir, das 14 pesquisas que dão voz ao professor formador de Letras em contexto de formação inicial selecionadas, 12 são dissertações, totalizando um percentual de $85,71 \%$ e somente 02 são teses, totalizando um percentual de $14,28 \%$ das pesquisas selecionadas.

\section{GRÁFICO 1}

Nível das pesquisas selecionadas nas três buscas realizadas no portal de teses e dissertações da Capes sobre o formador que atua na área de Letras

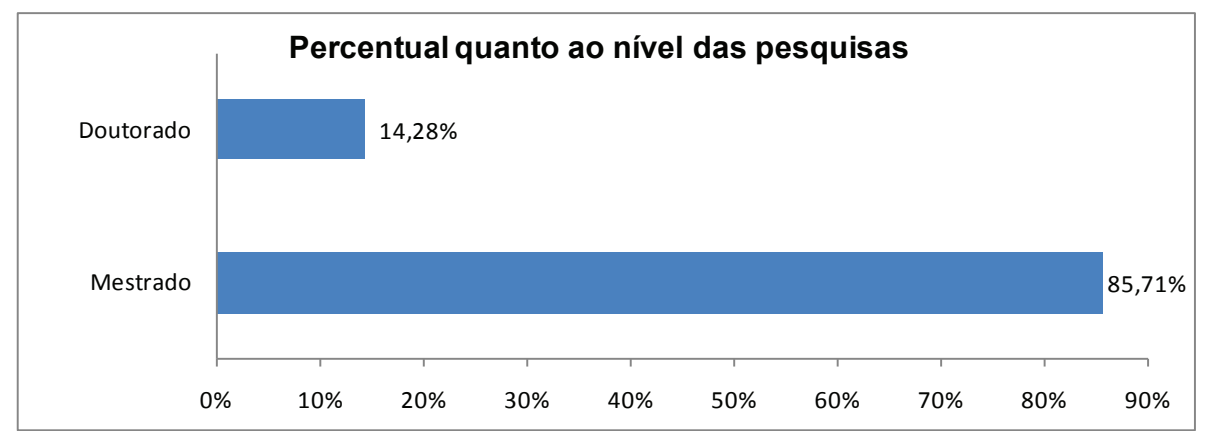

Fonte: Elaborado pela autora a partir do banco de teses e dissertaçôes da CAPES.

Com relação às 12 dissertações, 16,67\% são provenientes da área de Letras. No entanto, considero que podemos englobar as pesquisas desenvolvidas em cursos de pós-graduação em Linguística Aplicada, Linguística Aplicada e Estudos da Linguagem, Estudos da Linguagem e nos cursos Linguagem, Cultura e Discurso como subáreas dos cursos Letras. Sendo assim, considero que 58,33\% das pesquisas são provenientes de área/ subáreas de Letras e 41,67\% das dissertaçôes são provenientes de cursos de Mestrado em Educação. 


\section{GRÁFICO 2}

Percentuais de pesquisas quanto à área de conhecimento das dissertações selecionadas sobre formador que atua em Letras

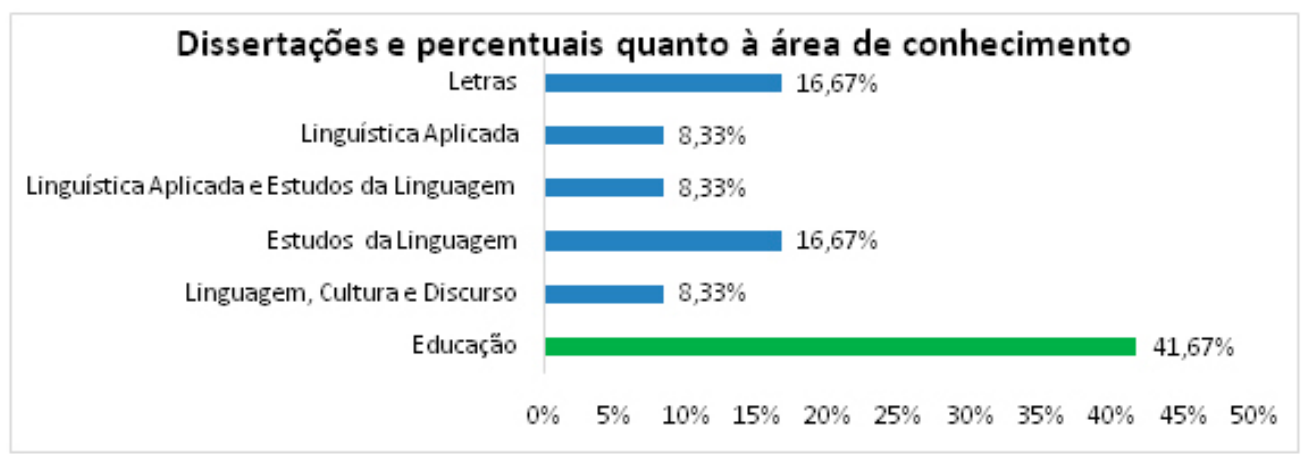

Fonte: Elaborado pela autora a partir do banco de teses e dissertações da CAPES.

Com relação as duas (02) teses de doutorado, o percentual das áreas de conhecimento das pesquisas se mostrou similar ao das dissertações uma vez que, uma (01) das teses selecionadas - a de Gonçalves (2006), ou seja, 50\% é proveniente de programas de cursos de pós-graduação em Letras e uma (01) delas - a de Costa (2010), corresponde aos outros 50\% das selecionadas, sendo essa última, resultado de tese desenvolvida em programa de doutorado em Educação. O gráfico 3 ilustra os percentuais relativos à área de formação das teses de doutorado.

\section{GRÁFICO 3}

Pesquisas e percentuais quanto à área de conhecimento das teses selecionadas sobre formador que atua em Letras

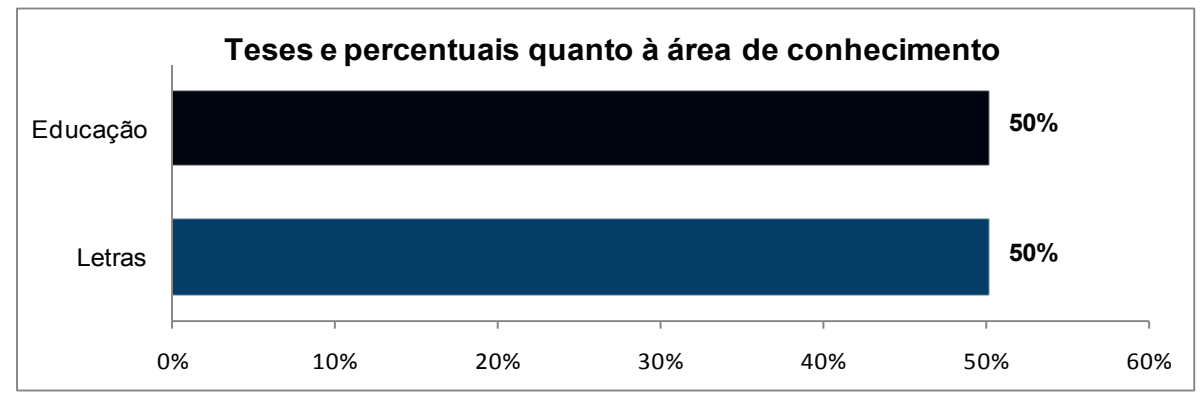

Fonte: Elaborado pela autora a partir do banco de teses e dissertaçōes da CAPES. 
Analisando essas 14 pesquisas selecionadas por meio das três buscas, observei que a questão do foco no professor formador é um interesse que não se restringe a pesquisadores de programas de pós-graduação de um campo específico do conhecimento, como é o caso de Letras e subáreas já elencadas, mas tem sido, igualmente, uma preocupação de pesquisadores de programas que englobam dificuldades gerais em processos de ensino/aprendizagem como ocorre nos Programas de Pós Graduação em Educação.

\section{Regiões do Brasil em que as pesquisas foram desenvolvidas}

O levantamento, por meio das três buscas, tornou também perceptível que as pesquisas, que têm focado e dado voz ao professor formador em contexto de formação inicial de professores de Letras, estão concentradas nas regiōes centro-oeste, sudeste e sul, ficando as regiōes norte e nordeste sem representatividade na exploração deste tema por meio desta característica específica para geração de dados.

$\mathrm{Na}$ região centro-oeste, há duas $(02)$ pesquisas provenientes da Universidade de Brasília - Viana (2011) e Bomfim (2008) com este perfil.

Mas, embora ainda pouco explorada, é nas regiões sudeste e sul que a geração de dados dando voz ao professor formador de Letras em contexto de formação inicial tem se destacado. Na região sudeste, especificamente, destaca-se o Estado de São Paulo. Toda a região sudeste totalizou seis (06) pesquisas, com a característica buscada, em apenas dois (02) dentre os quatro (04) Estados que compõem a região: São Paulo e Minas Gerais. Somente no Estado de São Paulo, verifiquei o desenvolvimento de cinco (05), dentre estas seis (06) pesquisas. A de Minas Gerais - Teles (2011) - foi desenvolvida na Universidade Vale do Rio Verde. Com relação as cinco (05) pesquisas realizadas em São Paulo, estas foram desenvolvidas em cinco (05) diferentes instituições que promovem cursos de pós graduação, sejam elas: a Universidade Presbiteriana Mackenzie - Almeida (2004); a Pontifícia Universidade Católica de Campinas - Chiareli (2005); a Universidade Estadual Paulista Júlio de Mesquita Filho - Gonçalves (2006); a Pontifícia Universidade Católica de São Paulo - Souto (2007); e, a Universidade Federal de São Carlos - Costa (2010).

Já na região sul, os três Estados que compõem a região contribuem com pesquisas. Das seis pesquisas encontradas sobre o tema, três (03), ou seja, a metade encontra-se nesta área no Estado do Paraná: Silva (2008) da 
Universidade Federal do Paraná; e, El Kadri (2010) e Registro (2010) da Universidade Estadual de Londrina. As três outras pesquisas distribuem-se da seguinte forma nos outros dois Estados da região: uma (01) em Santa Catarina - Danna (2012) da Universidade Regional de Blumenau; e, duas (02) no Rio Grande do Sul - Agostini (2008) e Lenz (2010), ambas da Universidade Federal de Santa Maria.

\section{GRÁFICO 4}

Regiōes do Brasil e instituições de elaboração/desenvolvimento das pesquisas sobre formador que atua na formação inicial de professores de Letras

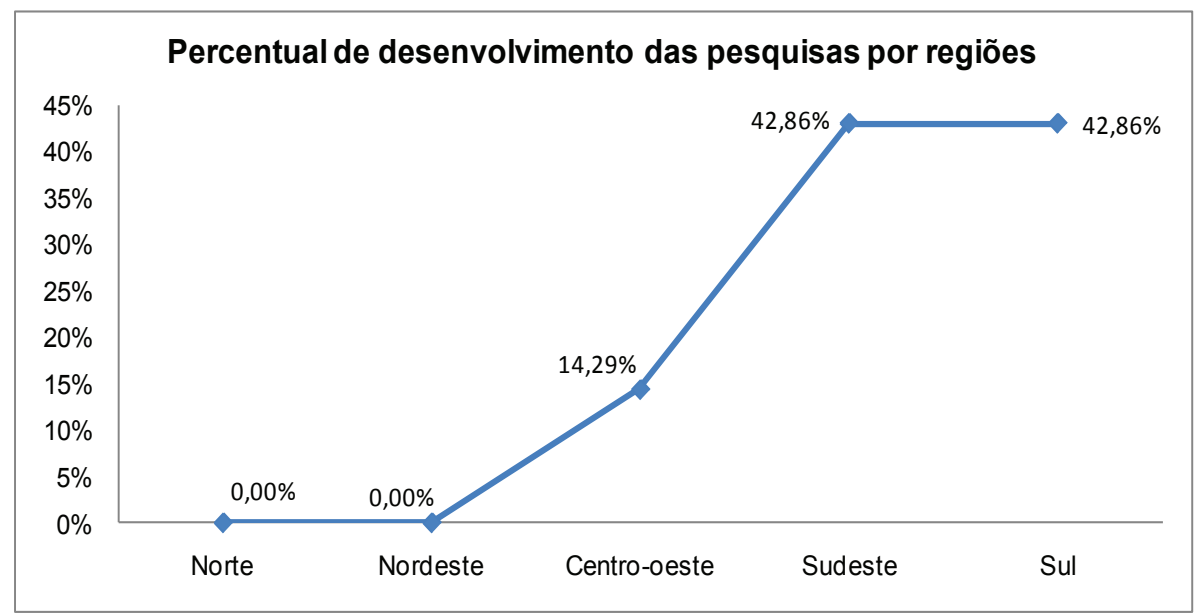

Fonte: Elaborado pela autora a partir do banco de teses e dissertaçôes da CAPES.

Saliento, ainda, que o crescimento do interesse pelo tema nas regiōes do Brasil foi estabelecido a partir das instituições promotoras dos cursos em que as pesquisas foram elaboradas, não considerando a origem do professor formador enfocado pelas pesquisas, o que poderia ampliar ainda mais o leque de regiōes abrangidas. Exemplifico este fato com a pesquisa desenvolvida por Costa (2010), que foi elaborada/desenvolvida em Instituição de Ensino Superior do Estado de São Paulo, mas que enfoca formadores de uma instituição pública de Ensino Superior da Bahia.

\section{Período de crescimento e concentração de pesquisas sobre o tema}

Assim como anteriormente explicitado, as três buscas foram realizadas conforme período estabelecido pelo banco de dados da Capes, ou seja, de 
1987 a 2012. Com relação ao período de concentração de pesquisas sobre o tema, todos os estudos são posteriores ao segundo milênio, sendo que sua primeira ocorrência data do ano de 2004 (Almeida). E, considerando os estudos realizados neste segundo milênio, constatei a elevação no número de estudos sobre este tema após o ano de 2007, comprovando que nos últimos anos houve um crescimento de pesquisas enfocando a formação inicial em Letras dando voz a seus formadores. O gráfico 5, ilustra o número de pesquisas desenvolvidas com esta característica no período de 1987 a 2012 bem como o seu ápice de desenvolvimento.

\section{GRÁFICO 5}

Período e ápice de desenvolvimento das pesquisas com foco no professor formador que atua no contexto de formação inicial em Letras

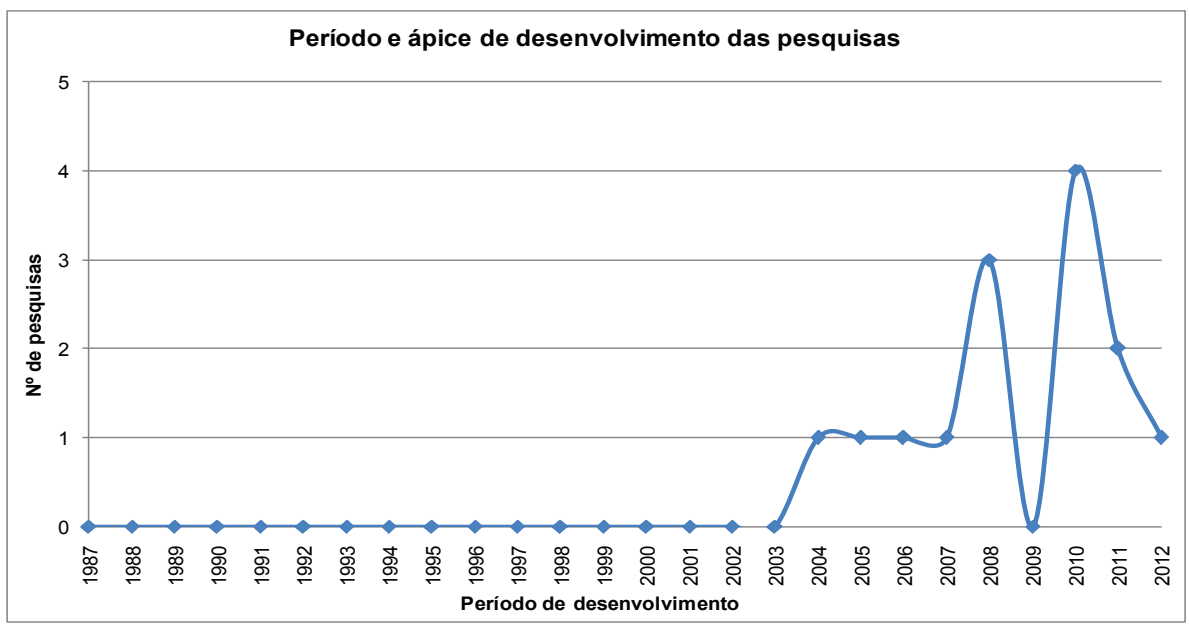

Fonte: Elaborado pela autora a partir do banco de teses e dissertaçôes da CAPES.

Portanto, dos quatorze (14) estudos selecionados nas três buscas no Banco de Teses e Dissertaçóes da Capes que geraram dados dando voz ao formador em contexto de formação inicial em Letras, dez (10) foram realizados entre 2008 e 2012, sendo que seu ápice encontra-se em 2010 perfazendo um total de quatro (04) pesquisas somente neste ano, em específico. 


\section{Instrumentos de geração de dados}

Analisando o capítulo referente à metodologia das 14 pesquisas selecionadas nas três buscas que mencionaram os instrumentos utilizados para dar voz, especificamente, ao professor formador em contexto de formação inicial em Letras, agrupei-os em nove (09) categorias procurando detalhar algumas variaçôes em suas aplicaçôes, quais sejam:

a) narrativas orais;

b) entrevistas ${ }^{11}$ - variando entre simples, semiestruturadas, narrativas e narrativas semiestruturadas;

c) questionários - abertos, fechados e mistos;

d) materiais didáticos;

e) trabalhos práticos dos alunos;

f) observação de aulas do formador - ocorrendo com gravação em áudio e/ou vídeo ou ambas as variaçôes seguidas ou não de transcriçôes, notas de campo do pesquisador combinadas com outros instrumentos tais como sessões reflexivas, grupo focal ou extensão ao coletivo e autoconfrontaçōes;

g) memorial descritivo e reflexivo;

h) grupo focal - ocorrendo por meio de grupo de discussão, entrevista com os participantes ou ainda na forma de extensão ao coletivo e de autoconfrontações simples e cruzadas;

i) coleta documental - podendo ser esta relacionada à: projetos pedagógicos de cursos, planos de aula e de ensino e/ou programas de disciplina do formador.

\footnotetext{
${ }^{11} \mathrm{~A}$ terminologia com relação aos instrumentos utilizados foi mantida conforme as dissertaçōes e teses consultadas.
} 


\section{GRÁFICO 6}

Número de ocorrências dos instrumentos utilizados para gerar enfocando o professor formador que atua no contexto de formação inicial em Letras

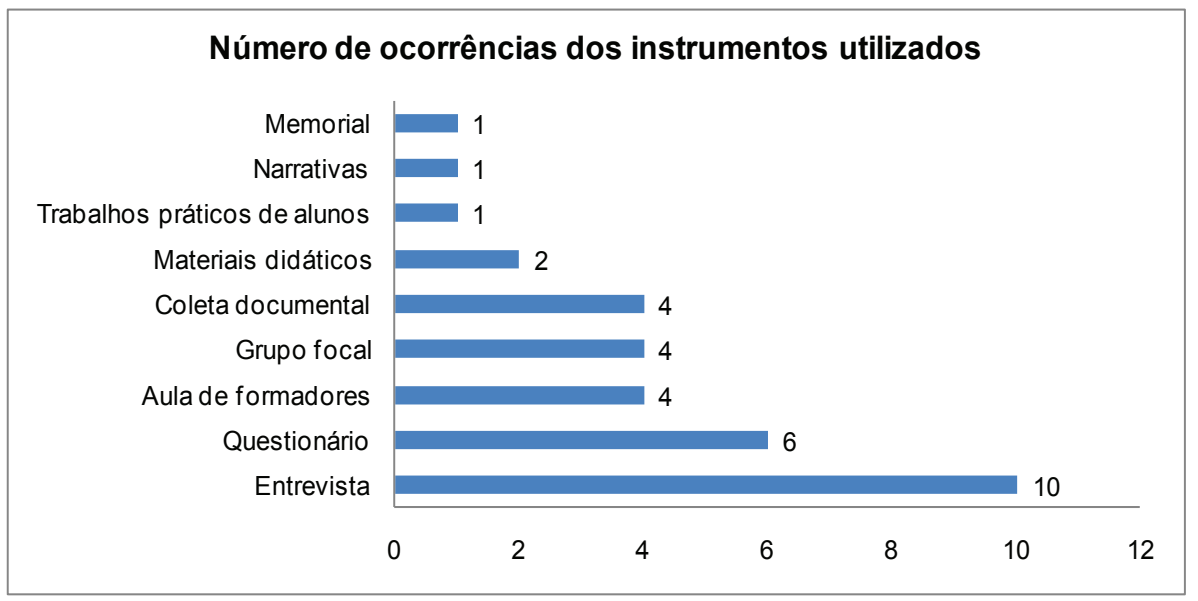

Fonte: Elaborado pela autora a partir do banco de teses e dissertações da CAPES.

De acordo com os instrumentos expostos no gráfico 6, dentre os mais utilizados nos 14 estudos estão, primeiramente, as entrevistas, utilizadas em 10 pesquisas, seguidas pelos questionários, empregados em 06 pesquisas. Como instrumentos de utilização intermediária, mencionados em 06 pesquisas, figuram a aula de formadores, o grupo focal e a coleta documental.

$\mathrm{E}$, finalmente, em somente três (03) das quatorze (14) pesquisas selecionadas - as de Almeida (2004), a de Lenz (2010) e a de Teles (2011) - há a utilização de um único instrumento. Na primeira o instrumento utilizado são os materiais didáticos fornecidos aos alunos pelo formador, na segunda são as entrevistas narrativas semiestruturadas aplicadas às formadoras e, na terceira, utiliza-se o memorial reflexivo e crítico.

O levantamento aqui apresentado não tem o intuito de atribuir ao instrumento mais utilizado o status de melhor instrumento para geração de dados no sentido de dar voz ao professor formador, mas sim de propiciar um panorama tanto quanto às diversas ferramentas das quais os pesquisadores têm se utilizado para esta finalidade e quais as que melhor têm se adequado aos objetivos das pesquisas desenvolvidas. 


\section{QUADRO 4}

Instrumentos de geração de dados e a área específica de atuação dos formadores investigados

\begin{tabular}{|c|c|c|c|c|c|c|c|c|c|}
\hline \multirow[b]{2}{*}{ Pesquisas } & \multicolumn{9}{|c|}{ Instrumentos } \\
\hline & 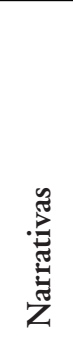 & 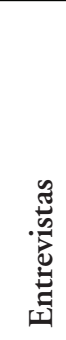 & 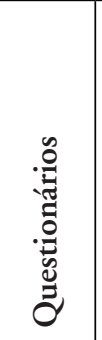 & 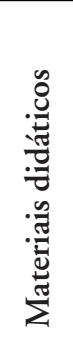 & 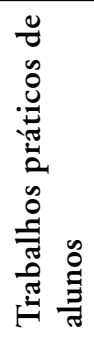 & 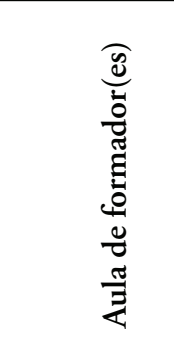 & 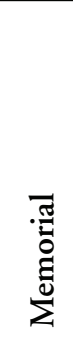 & 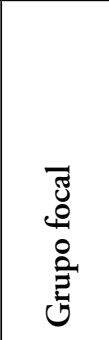 & 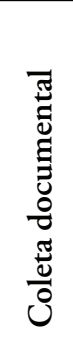 \\
\hline Almeida (2004) & & & & NC & & & & & \\
\hline Chiareli (2005) & & $\mathrm{CE}$ & $\mathrm{CE}$ & & & & & & \\
\hline Gonçalves (2006) & & $\mathrm{CE}$ & & $\mathrm{CE}$ & & $\mathrm{CE}$ & & & \\
\hline Souto (2007) & & $\mathrm{PE}$ & $\mathrm{PE}$ & & & & & & \\
\hline Bomfim (2008) & $\mathrm{PE}$ & $\mathrm{PE}$ & & & & $\mathrm{PE}$ & & PE & \\
\hline Silva (2008) & & & & & & CE/PE/AM & & 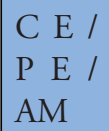 & \\
\hline Agostini (2008) & & $\mathrm{PE}$ & $\mathrm{PE}$ & & & & & $\mathrm{PE}$ & $\mathrm{PE}$ \\
\hline Costa, 2010 & & LD & & & & & & & \\
\hline El Kadri (2010) & & $\mathrm{CE}$ & $\mathrm{CE}$ & & & & & & $\mathrm{CE}$ \\
\hline Lenz (2010) & & $\mathrm{CE}$ & & & & & & & \\
\hline $\begin{array}{l}\text { Rios-Registro } \\
(2010)\end{array}$ & & & $\begin{array}{l}\mathrm{CE} / \\
\mathrm{PE}\end{array}$ & & $\begin{array}{l}\mathrm{CE} / \\
\mathrm{PE}\end{array}$ & & & $\begin{array}{l}\mathrm{C} \mathrm{E} / \\
\mathrm{PE}\end{array}$ & $\begin{array}{l}\mathrm{CE} / \\
\mathrm{PE}\end{array}$ \\
\hline Viana (2011) & & PE & $\mathrm{PE}$ & & & $\mathrm{PE}$ & & & \\
\hline Teles (2011) & & & & & & & $\mathrm{CE}$ & & \\
\hline Danna (2012) & & $\mathrm{CE}$ & & & & & & & $\mathrm{CE}$ \\
\hline \multicolumn{10}{|c|}{ Legendas } \\
\hline $\mathrm{CE}$ & \multicolumn{4}{|c|}{ Conteúdo Específico } & \multicolumn{2}{|r|}{$\mathrm{E} / \mathrm{PE}$} & \multicolumn{3}{|c|}{\begin{tabular}{|l|} 
Conteúdo \\
Específico e Prática \\
de Ensino \\
\end{tabular}} \\
\hline PE & Práti & $\mathrm{ade}$ & sino & & & CE/PE/AM & \multicolumn{3}{|c|}{$\begin{array}{l}\text { Conteúdo } \\
\text { Específico, Prática } \\
\text { de Ensino e Área } \\
\text { Mista }\end{array}$} \\
\hline $\mathrm{LD}$ & \multicolumn{4}{|c|}{ Licenciaturas Diversas } & & $\mathrm{NC}$ & \multicolumn{3}{|c|}{ Nada Consta } \\
\hline
\end{tabular}

Fonte: Elaborado pela autora a partir do banco de teses e dissertações da CAPES. 


\section{7 Área específica de atuação dos formadores investigados}

Com relação à área específica de atuação dos formadores investigados, dentre os 14 estudos selecionados, há um (01) único estudo - o de Almeida, 2004 - que apesar do título evidenciar o foco no professor formador, não explicita, em seu resumo, a área de atuação do formador envolvido na geração de dados nem os instrumentos utilizados para possibilitar a voz ao formador de professores de Letras em contexto de formação inicial. Quanto às demais treze (13) pesquisas, a maioria dos formadores envolvidos na geração de dados enquadra-se em duas grandes áreas: a de conteúdo específico e a de prática de ensino.

As pesquisas enfocando somente formadores da área de conteúdo específico (CE) totalizam seis (06): Chiareli (2005), Gonçalves (2006), El Kadri (2010), Lenz (2010), Teles (2011), Danna (2012).

Já as pesquisas exclusivamente focalizando formadores de prática de ensino (PE) totalizam quatro (04): as de Bomfim, Viana (2011), Souto (2007) e Agostini (2008).

Mas, há também, aquelas cuja a participação contemplou tanto formadores de conteúdo específico quanto formadores de prática de ensino (CE/PE) - a de Silva (2008) e a de Registro (2010). No entanto, a de Silva (2008) difere da de Registro (2010) por enfocar a perspectiva de professores não somente responsáveis por uma das áreas - de conteúdo específico e/ou de prática de ensino - mas também propicia a voz ao formador que, dentre suas funções, exerce a de coordenar e organizar as diversas disciplinas que compóem a matriz curricular de um curso: o formador coordenador de curso (CE/PE/AM).

E finalmente, houve também um (01) caso - Costa (2010) - que gerou dados a partir da contribuição de formadores de forma geral sem a preocupação de revelar a área específica de atuação dos docentes, isto é, se os sujeitos participantes eram provenientes da área de CE ou PE. Além disto, este último estudo não apenas tem como sujeitos os formadores de Licenciaturas em Letras, mas, do mesmo modo, conta com a participação de também formadores de licenciaturas diversas (LD).

Desta forma, observando as áreas de atuação dos formadores investigados, sua maior concentração está na geração de dados a partir de professores responsáveis pelas disciplinas de CE (42.86\%), isto sem considerar as pesquisas em que tanto os professores de $\mathrm{CE}$ quanto os de $\mathrm{PE}$ foram foco de geração de dados. 


\section{GRÁFICO 7}

Percentual de ocorrência das áreas de atuação dos formadores investigados em 13 das 14 pesquisas

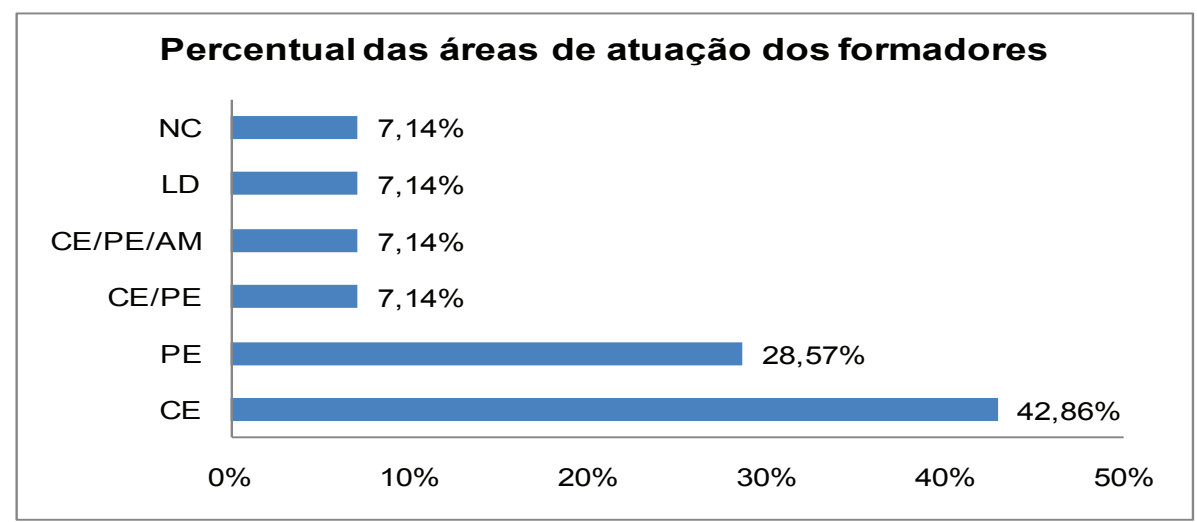

Fonte: Elaborado pela autora a partir do banco de teses e dissertações da CAPES.

Para compreender melhor a área de atuação dos formadores investigados, procurei especificar as disciplinas pelas quais estes sujeitos da pesquisa são responsáveis. Assim, foram mencionados formadores de sete (07) disciplinas distintas pertencentes à primeira área (CE): Leitura e Escrita/Letramento Língua Materna, Língua Inglesa, Literatura de Língua Inglesa, Análise Crítica do Discurso, Gênero Textual para o ensino de Língua Estrangeira, Introdução à tradução em Língua Inglesa e Introdução à Linguística Sistêmico Funcional.

Com relação à segunda área (PE), adotando o mesmo critério estabelecido para o agrupamento feito quanto à primeira área (CE), isto é, considerando não somente aquelas pesquisas que enfocaram unicamente os formadores da área de PE, mas também aquelas que tiveram como sujeitos de pesquisa formadores de $\mathrm{CE} / \mathrm{PE}$, observei o mesmo número de disciplinas elencadas na primeira área, ou seja, sete (07) disciplinas: Orientação de Estágio de Língua Inglesa, Prática de Ensino de Língua Inglesa, Metodologia de Ensino de Língua Inglesa, Métodos e Prática de Ensino de Língua Inglesa, Metodologia de Ensino de Línguas Estrangeiras Modernas, Didática dos cursos Letras, Matemática, História e Geografia. 


\section{GRÁFICO 8}

Percentual referente às 14 disciplinas de $\mathrm{CE}$ e $\mathrm{PE}$ em que atuam os formadores investigados

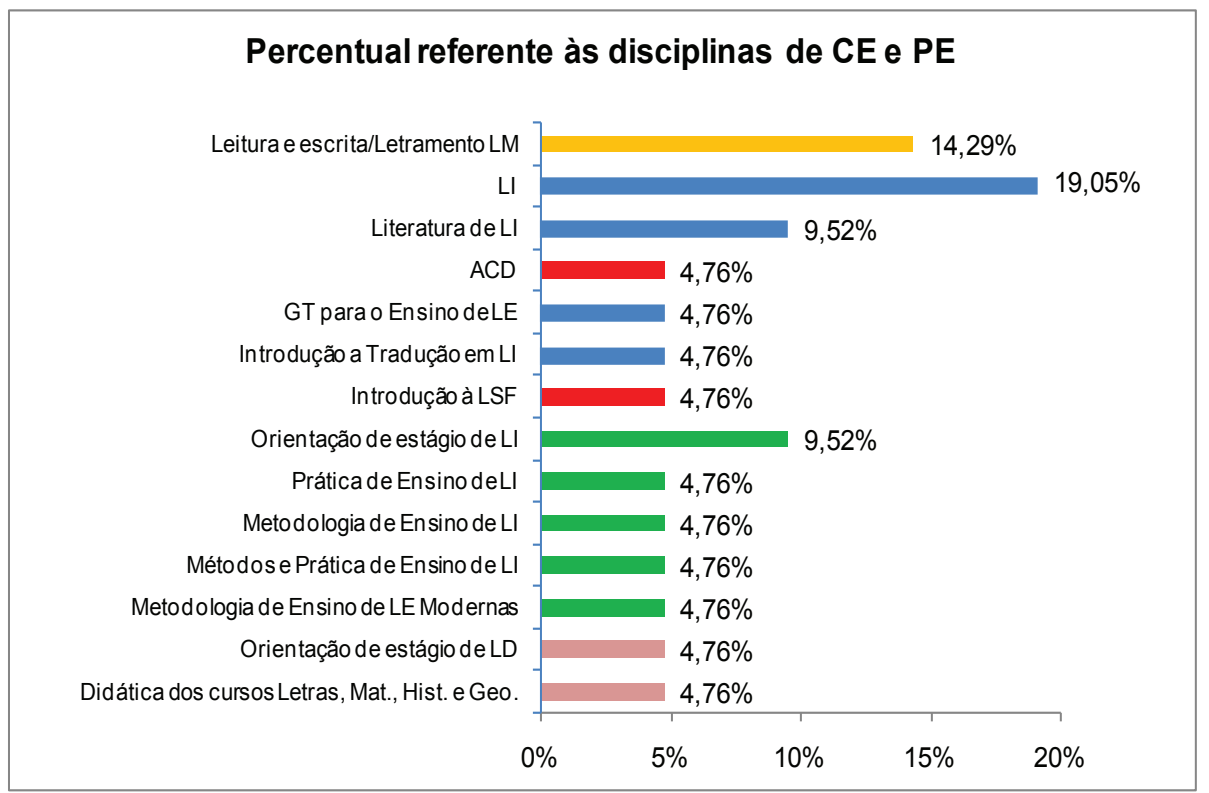

Fonte: Elaborado pela autora a partir do banco de teses e dissertaçôes da CAPES.

Saliento que quatro (04) pesquisas, dentre as seis (06) que exploram dados dos formadores de PE - as de Bomfim (2008), Viana (2011); Silva (2008) e Registro (2010) - têm como participantes, formadores de disciplinas de Língua Estrangeira (LE) destacando-se aí o formador de PE de Língua Inglesa(LI). Por outro lado, há uma única pesquisa de PE que não se destina somente ao professor formador de LE (SOUTO, 2007). Talvez esta ênfase em pesquisas sobre o professor formador de LE esteja embasada nas dificuldades que estes formadores estão tendo em formar satisfatoriamente os alunos/professores de forma a prepará-los para enfrentar as adversidades vivenciadas pelos professores de LE no ensino básico.

De forma geral, destaco também, os estudos desenvolvidos por Viana, (2011) e Souto (2007) que deram voz tanto aos professores formadores quanto aos alunos/professores em sua geração e análise de dados apresentando um diferencial entre as 14 pesquisas selecionadas por meio de minhas três buscas. Aliás, a pesquisa de Viana (2011) é a única que se propõe a gerar e 
analisar dados a partir de quatro perspectivas: a de duas formadoras atuantes na disciplina de Metodologia de Ensino de Línguas Estrangeiras Modernas; a de duas alunas/professoras formandas; a da realidade observada; e, ainda, a perspectiva do que é proposto pelas diretrizes curriculares. Já a pesquisa de Souto (2007) destaca-se por ter envolvido professores formadores não só de Letras, mas de 03 outras licenciaturas - Matemática, História e Geografia bem como seus cento e quinze (115) licenciandos.

\section{Considerações finais}

O objetivo de minhas três buscas foi o de detectar não somente se havia pesquisas sendo desenvolvidas a partir da análise do agir do professor formador de Letras em contexto de formação inicial, mas também o de identificar se alguma delas, paralelamente, gerava dados dando voz a todos os integrantes do corpo docente de um determinado curso de Letras para que eles se pronunciassem acerca de seu trabalho educacional. Porém, embora as 14 pesquisas selecionadas e aqui apresentadas tenham envolvido de alguma forma professores da área de $\mathrm{CE}, \mathrm{PE}, \mathrm{AM}$ e de $\mathrm{LD}$, não identifiquei nenhuma, dentre as registradas no banco de teses e dissertaçóes da Capes, com esta característica em minhas três buscas.

Assim, encerro este cenário de pesquisas sobre o formador de professor de Letras que atua em contexto de formação inicial de professores expressando minha concordância com Calvo (2013) de que estudos com foco no trabalho do formador de Letras ainda são incipientes. Entretanto, compreendo que, embora ainda sejam em número que pode ser considerado reduzido, os 14 estudos apresentados representam uma mudança significativa no enfoque das pesquisas, ou seja, o foco deixa de ser exclusivamente no aluno/professor em formação inicial ou no professor da Educação Básica em formação continuada e passa a contemplar também o formador de professores como sujeito de pesquisa. Pesquisas neste âmbito podem contribuir para que se faça conhecer a voz dos formadores acerca de seu trabalho educacional como uma das possibilidades de superação dos vários desafios que circundam os cursos de Licenciatura.

\section{Referências}

CALVO, L. C. S. Reflexōes sobre uma comunidade de prática constituida a partir das interações de formadoras de professores de inglês em um grupo de estudos. $2013.191 \mathrm{f}$. Tese (Doutorado em Estudos da Linguagem) - Universidade Estadual de Londrina, Londrina, 2013. 
CHIARELI, M. P. B. As Abordagens de Ensino de Lingua Estrangeira em Cursos de Letras: uma visão do docente formador. 2005, 155f. Dissertação (Mestrado em Educação). Campinas, 2005.

COSTA, J. S. A docência do professor formador de professores. 2010, 124f. Tese (Doutorado em Educação) São Carlos, São Paulo, UFSCar 2010.

DANNA, C. L. Sentidos sobre práticas de leitura e escrita em Letras: com a palavra professores formadores. 2010,128f. Dissertação (Mestrado em Educação) Fundação Universidade Regional de Blumenau, Santa Catarina, 2012.

EL KADRI, M. S. O estatuto do inglês como língua franca em um curso de formação inicial de professores. 2010, 213f. Dissertação (Mestrado em Estudos da Linguagem). Universidade Estadual de Londrina, 2010.

FREITAS, M. A. Ensino em time por professoras-formadoras (inglês). Um ritmo constante de fragmentaçōes, fluidez, contradiçōes. Tese (Doutorado em Letras) Faculdade de Ciências e Letras de Assis, Universidade Estadual Paulista, Assis, 2004. GIL, G. Mapeando os estudos de formação de professores de línguas no Brasil. In: M. FREIRE; M.H. VIEIRA-ABRAHĀO; A.M. BARCELOS (Orgs.). Linguistica Aplicada e Contemporaneidade. Campinas: Pontes, p.173-182, 2005.

GIMENEZ, T. Desafios contemporâneos na formação de professores de línguas: contribuiçōes da Linguística Aplicada. In: FREIRE, M. M.; VIEIRA-ABRAHÃO, M. H.; BARCELOS, A. M. F (Org.). Linguistica Aplicada e contemporaneidade. Campinas: ALAB/Pontes, 2005a. p.183-201.

GIMENEZ, T. Currículo e identidade profissional nos cursos de Letras / inglês. In: TOMICH, L. M. B; VIEIRA-ABRAHÃO, M. H.; DAGHLIN, C.; RISTOFF, D. I. (Org.). A interculturalidade no ensino de Inglês. Florianópolis: UFSC, $2005 \mathrm{~b}$. p. 331-343.

GIMENEZ, T.; CRISTÓVÃO, V.L.L. Formadores de Professores de Inglês como Pesquisadores. In: GIMENEZ, T. (Org.). Tecendo as manhâs: pesquisa participativa e formação de professores de inglês. Londrina: UEL, p. 1-22, 2007.

GIMENEZ, T.; CRISTOVÃO, V. L. L. Derrubando paredes e construindo pontes: formação de professores de língua inglesa na atualidade. Revista Brasileira de Linguistica Aplicada, Belo Horizonte, MG, vol. 4, n. 2, 2004, p. 8595.

GONÇALVES, J. R. Pressupostos teóricos e metodológicos presentes na prática do docente formador de professores de inglês. Tese (Doutorado em Letras) Universidade Estadual Paulista Júlio de Mesquita Filho, São Paulo, 2006.

HALU, R. C. Formação de Formadoras de professores de inglês em contexto de formação continuada (NAP-UFPR). 2010. 246 f. Tese (Doutorado)-Programa de PósGraduação em Letras, Universidade Federal do Paraná, Curitiba, 2010. 
LENZ, N. A constituição da docência no Ensino Superior em Letras: de professor da educação básica a docente universitário. 2010, 173f. Dissertação (Mestrado em Educação) Universidade Federal de Santa Maria, SC, 2010.

NEDER, A. V. Memória do múltiplo e do descontínuo nos discursos de construção de um curso de Letras de formação de professores: IEL/UNICAMP. 1995, 176f. Dissertação (Mestrado em Linguística Aplicada) Universidade Estadual de Campinas, Campinas, 1995.

ORTENZI, D. I. B. G. A produção coletiva de um material pedagógico para a prática de ensino de inglês. 2007, 282f. Tese (Doutorado)-Programa de Pós-graduação em Estudos da Linguagem, Universidade Estadual de Londrina, Londrina, 2007.

PAIVA, V. M. O. P. O novo perfil dos cursos de licenciatura em Letras. In: TOMICH, L. M. B; VIEIRA-ABRAHÃO, M. H.; DAGHLIN, C.; RISTOFF, D. I. (Org.). A interculturalidade no ensino de Inglês. Florianópolis: UFSC, 2005, p. 345-363.

PAIVA, V. M. O. P. Avaliação dos cursos de Letras e a formação do professor. In: Revista do GELNE. João Pessoa, v. 5, n.1 e 2, p.193-200, 2004.

PÉRILLAT, L. H. G. A formação inicial do professor de inglês: o olhar do aluno. 2011, 97f. Dissertação (Mestrado em Linguística Aplicada). Pontifícia Universidade Católica de São Paulo, São Paulo, 2011.

PERIN, J. O. R. Emergência e construção de uma comunidade de prática de formadores de professores de lingua inglesa. 2009, 265f. Tese (Doutorado)-Programa de PósGraduação em Estudos da Linguagem, Universidade Estadual de Londrina, Londrina, 2009.

REGISTRO, E.S.R. A relação entre prescrição, representações e agir docente: um estudo de caso em um curso de formação inicial. 2010, 199f. Dissertação (Mestrado em Estudos da Linguagem). Universidade Estadual de Londrina, Londrina, 2010. SALOMÃO, A. C. B. Formadores de professores de Língua Inglesa: uma experiência de colaboração e reflexão. In: RBLA, Belo Horizonte, v. 11, n. 3, p. 653-677, 2011. SARAIVA, S. D. R. Narrativas sobre prática pedagógica e desenvolvimento profissional: Administradores-professores de ensino superior como protagonistas. 2010,118f. Dissertação (Mestrado em Educação) Universidade Federal do Piauí, Piauí, 2010. SILVA, A. A.P. Trabalho docente: um estudo de representação em textos do professorformador acerca do papel da disciplina de língua inglesa no curso de Letras. 2008, 187p. Dissertação (Mestrado em Letras) Universidade Federal do Paraná, Curitiba, 2008.

SILVA, K. A. Crenças e Aglomerados de Crenças de Alunos Ingressantes em Letras/ Inglês. 2005. 217p. Dissertação (Mestrado em Linguística Aplicada) Universidade Estadual de Campinas, Campinas/SP, 2005. 
SILVA, L. L. P. Cognições de professores sobre pesquisas relacionadas ao processo de ensino e aprendizagem de LE - um estudo "Q". 2012. 182 f. Dissertação (Mestrado)Universidade Federal de Uberlândia, Uberlândia, 2012.

SILVEIRA, A. P. K. O lugar dos Gêneros nos projetos e relatórios de estágio do curso de graduação em Letras Inglês/Português da Universidade Regional de Blumenau. 2009, 289p. Dissertação (Mestrado em Linguística) Universidade Federal de Santa Catarina, Santa Catarina, 2009.

SOUTO, B. N. R. Ensinar a ensinar e aprender a ensinar: representaçôes de professores e alunos em relação à formação inicial dos cursos de Licenciatura na Universidade Federal do Amapá. 2007, 118p. Dissertação (Mestrado em Educação) Pontifícia Universidade Católica de São Paulo, São Paulo, 2007.

TELES, I S. R. Memorial reflexivo: história e análise de uma trajetória profissional docente. 2011. 84p. Dissertação (Mestrado em Linguagem, Cultura e Discurso) Universidade Vale do Rio Verde - UNINCOR, Três Coraçôes, MG, 2011.

VIANA, K. M. N. Baseado em fatos reais: papéis do formador na (trans)formação inicial do professor de língua inglesa. 2011, 159f. Dissertação (Mestrado em Linguística Aplicada). Universidade de Brasília, Brasília, 2011.

VIEIRA-ABRAHÃO, M. H. The construction of theoretical and practical knowledge in initial education. In: Profile: Issues in Teachers' Professional Development. Universidade Nacional da Colômbia, v. 7, p. 87-99, 2006.

VIEIRA-ABRAHÃO, M. H. (Org.). Prática de Ensino de Lingua Estrangeira: experiências e reflexões. Campinas: Pontes, 2004.

Data de submissão: 02/09/2014. Data de aprovação: 13/01/2015. 